\title{
Bortezomib inhibits Burkitt's Iymphoma cell proliferation by downregulating sumoylated hnRNP K and c-Myc expression
}

\author{
Fat-Moon Suk ${ }^{1,2, *}$, Shyr-Yi Lin ${ }^{3,4, *}$, Ren-Jye Linn ${ }^{3,4}$, Yung-Hsin Hsine ${ }^{5}$, Yen-Ju Liao ${ }^{5}$, \\ Sheng-Uei Fang ${ }^{2,6}$, Yu-Chih Liang ${ }^{5,7}$ \\ ${ }^{1}$ Division of Gastroenterology, Department of Internal Medicine, Wan Fang Hospital, Taipei Medical University, Taipei, Taiwan \\ ${ }^{2}$ Department of Internal Medicine, School of Medicine, College of Medicine, Taipei Medical University, Taipei, Taiwan \\ ${ }^{3}$ Department of Primary Care Medicine, Taipei Medical University Hospital, Taipei, Taiwan \\ ${ }^{4}$ Department of General Medicine, School of Medicine, College of Medicine, Taipei Medical University, Taipei, Taiwan \\ ${ }^{5}$ School of Medical Laboratory Science and Biotechnology, College of Medical Science and Technology, Taipei Medical \\ University, Taipei, Taiwan \\ ${ }^{6}$ Division of Gastroenterology and Hepatology, Department of Internal Medicine, Taipei Medical University Hospital, Taipei, \\ Taiwan \\ ${ }^{7}$ Traditional Herbal Medicine Research Center, Taipei Medical University Hospital, Taipei, Taiwan \\ *These authors have contributed equally to this work \\ Correspondence to: \\ Yu-Chih Liang, e-mail: ycliang@tmu.edu.tw
}

Keywords: Bortezomib, Burkitt's lymphoma, hnRNP K, sumoylation, c-Myc

Received: April 02, $2015 \quad$ Accepted: July 06, 2015

Published: July 17, 2015

\section{ABSTRACT}

Bortezomib (Velcal) was the first proteasome inhibitor to be approved by the US Food and Drug Administration to treat patients with relapsed/refractory multiple myelomas. Previous studies have demonstrated that bortezomib inhibits tumor cell proliferation and induces apoptosis by blocking the nuclear factor (NF)-kB pathway. However, the exact mechanism by which bortezomib induces cancer cell apoptosis is still not well understood. In this study, we found that bortezomib significantly inhibited cell proliferation in both human Burkitt's Iymphoma CA46 and Daudi cells. Through proteomic analysis, we found that bortezomib treatment changed the expression of various proteins in distinct functional categories including unfolding protein response (UPS), RNA processing, protein targeting and biosynthesis, apoptosis, and signal transduction. Among the proteins with altered expression, hnRNP K, hnRNP H, Hsp90a, Grp78, and Hsp7C were common to both Daudi and CA46 cells. Interestingly, bortezomib treatment downregulated the expression of high-molecular-weight (HMw) hnRNP K and c-Myc but upregulated the expression of low-molecular-weight (LMw) hnRNP K. Moreover, cell proliferation was significantly correlated with high expression of HMw hnRNP $K$ and c-Myc. HMw and LMw hnRNP $K$ were identified as sumoylated and desumoylated hnRNP K, respectively. Using transient transfection, we found that sumoylated hnRNP $K$ increased c-Myc expression at the translational level and contributed to cell proliferation, and that Lys422 of hnRNP K is the candidate sumoylated residue. Our results suggest that besides inhibiting the ubiquitinproteasome pathway, bortezomib may inhibit cell proliferation by downregulating sumoylated hnRNP $K$ and c-Myc expression in Burkitt's lymphoma cells. 


\section{INTRODUCTION}

Burkitt's lymphoma is an aggressive B-cell type of non-Hodgkin's lymphoma [1]. Burkitt's lymphoma occurs endemically in areas with malaria exposure [2] and is associated with Epstein-Barr virus (EBV) infections [3]. Most Burkitt's lymphomas overexpress the Myc oncogene that promotes cell cycle progression and contributes to tumor formation [4]. Overexpression of Myc mostly results from its translocation to an immunoglobulin gene, such as the $t(8 ; 14)(\mathrm{q} 24 ; \mathrm{q} 32)$ translocation found in approximately $85 \%$ of Burkitt's lymphomas cases. Chemotherapeutic regimens can produce good prognoses for patients with Burkitt's lymphoma [5]. High doses of methotrexate, cytosine arabinoside, and cyclophosphamide, whether or not in combination with a specific antibody (e.g., rituximab) [6], are useful chemotherapeutic drugs.

Proteasomes are multi-protein complexes and are responsible for ubiquitin-mediated protein degradation [7]. Dysregulation of proteasome activity may increase endoplasmic reticular (ER) stress, which ultimately results in apoptosis [8] and contributes to several diseases such as Parkinson's and Alzheimer's diseases $[9,10]$. Inhibition of proteasome activity has been developed as a new strategy to induce tumor cell apoptosis [11]. Bortezomib, a dipeptidyl boronic acid proteasome inhibitor, was the first proteasome inhibitor to be approved by the US Food and Drug Administration (FDA) in 2003 for treating multiple myelomas and mantle cell lymphomas [12]. Besides inhibition of proteasome activity, bortezomib can also induce apoptosis by interrupting the DNA repair and unfolded protein response pathways, and by inhibiting proliferation and survival signal molecules such as $\mathrm{PI}_{3} \mathrm{~K}$, mitogen-activated protein kinase (MAPK), and nuclear factor (NF)-kB [13]. Bortezomib activates the c-Jun N-terminal kinase (JNK) signal pathway and increases caspase- 3 and caspase-8 levels in multiple myelomas [14]. In human pancreatic cancer cells, bortezomib induces apoptosis by inhibiting the PKR-like endoplasmic reticulum kinase (PERK) and increasing ER stress [15]. Additionally, bortezomib can induce apoptosis in cancer cells by increasing the release of reactive oxygen species (ROS) and cytochrome $\mathrm{C}$ from mitochondria, as well as by activating caspase- 3 and caspase-9 $[13,16]$.

Heterogeneous nuclear ribonucleoprotein K (hnRNP K) is located mainly in the nucleus [17], where it regulates DNA repair, transcription, chromatin remodeling, and telomere elongation [18]. Additionally, hnRNP $\mathrm{K}$ shuttles between the nucleus and the cytoplasm and participates in 3 '-end modification and cleavage of pre-messenger (m)RNA and mRNA stability [19]. Previous studies have indicated that the functions and activities of hnRNP $\mathrm{K}$ are affected by various modifications including phosphorylation [20-22], methylation [23], ubiquitination [24], and sumoylation $[25,26]$. Increased levels of hnRNP K are correlated with cancer cell proliferation and metastasis, and are implicated in the regulation of oncogene $c-M y c$ transcription [27] and translation [28], as well as oncogene $c$-Src transcription [20].

Small ubiquitin-like modifiers (SUMOs) comprise a small protein family that contains at least four isoforms including SUMO-1, SUMO-2, SUMO-3, and SUMO-4. SUMOs can covalently bind to lysine residues of proteins such as $\mathrm{p} 53, \mathrm{I} \mathrm{\kappa B}, \mathrm{PML}$, and c-Jun, affecting their subcellular localization, transcriptional activity, and protein stability [29]. Sumoylation can be reversed by sentrin/SUMO-specific proteases (SENPs) that remove SUMO molecules from sumoylated proteins [30]. Recent reports have indicated that sumoylation regulates tumorigenesis. Ubc9, a SUMO-conjugating enzyme, is overexpressed in ovarian cancer [31], and sumoylated reptin increases metastatic potential by repressing the metastasis-suppressor gene KAII [32]. Sumoylated interferon regulatory factor (IRF)-1 competes with non-sumoylated IRF-1 to inhibit cytokine-mediated apoptosis, which results in tumor cell proliferation [33].

Both hnRNP K and sumoylation have been shown to play roles in the tumorigenesis; however, whether there is a link between hnRNP K and sumoylation, and Burkitt's lymphoma, is not clear till date. In this study, we examined the influence of bortezomib on protein expression in Burkitt's lymphoma cells, and the relationship between inhibition of proliferation and downregulation of sumoylated hnRNP K by bortezomib.

\section{RESULTS}

\section{Bortezomib inhibits Burkitt's lymphoma cell proliferation}

The Daudi and CA46 cell lines are both derived from human Burkitt's lymphoma cells and express high levels of c-Myc and BCL-2. However, Daudi cells are EBV nuclear antigen (EBVA)-positive, while CA46 cells are EBVA-negative. To investigate whether bortezomib can inhibit proliferation of human Burkitt's lymphoma cells, we used both Daudi and CA46 cells. As shown in Fig. 1, bortezomib significantly decreased the viable cell numbers in dose- and time-dependent manners. The half maximal inhibitory concentration $\left(\mathrm{IC}_{50}\right)$ of bortezomib was approximately $10 \mathrm{nM}$ at $12 \mathrm{~h}$ in Daudi CA46 cells, and approximately $50 \mathrm{nM}$ at $24 \mathrm{~h}$ in CA46 cells. Prolonged treatment with bortezomib at $\mathrm{IC}_{50}$ concentrations resulted in gradual shrinking of the cells followed by cell death. Therefore, cells were treated at $\mathrm{IC}_{50}$ concentrations in the proteomic analysis. 
A.

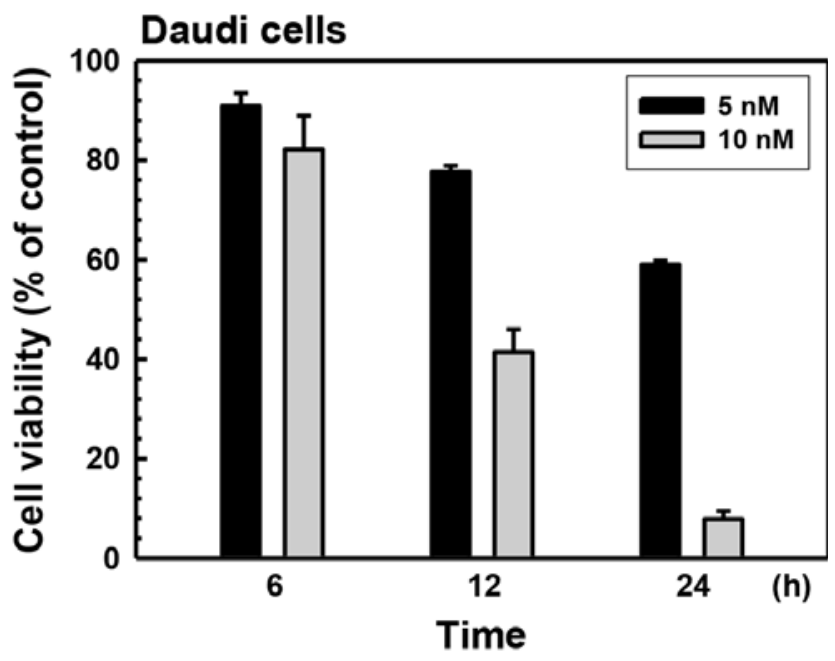

B.

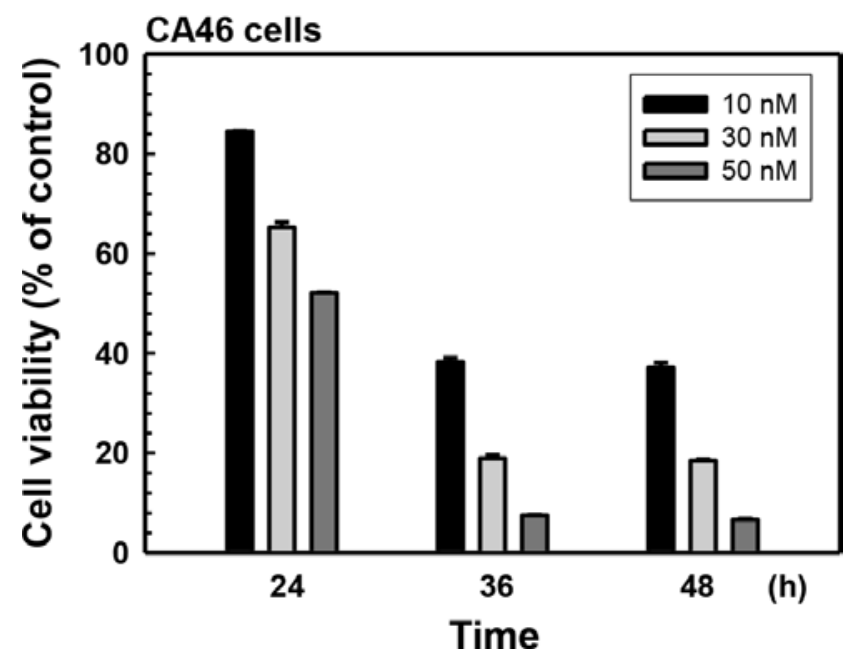

Figure 1: Inhibitory effects of bortezomib on the proliferation of human Burkitt's lymphoma cells. A. Daudi and B. CA46 cells were treated with various concentrations of bortezomib for different periods, and the viable cells were determined by MTT assay. The data are presented as mean \pm S.E. of three independent experiments.

\section{Proteomic analysis of altered proteins in bortezomib-treated Burkitt's lymphoma cells}

To investigate which proteins are altered in bortezomib-treated Burkitt's lymphoma cells, the expression profiles of bortezomib-treated CA46 and Daudi cells were analyzed by using two-dimensional electrophoresis and MALDI-TOF/MS. With a fixed threshold of 2.0, the expression of 96 proteins in Daudi cells and of 60 proteins in CA46 cells was found to significantly differ between control and bortezomib-treated cells. However, only 26 of the proteins in Daudi cells were identified by using MALDI-TOF/MS followed by a database search (Table 1). Of these 26 proteins, 17 were significantly upregulated, and 9 were significantly downregulated in bortezomib-treated cells. The altered proteins are presented in Fig. 2. In CA46 cells, 24 proteins belonging to 22 protein classes were identified, among which 19 were significantly upregulated and 5 significantly downregulated in bortezomib-treated cells (Supplementary Table S1). Five proteins were altered in both bortezomibtreated Daudi and CA46 cells, including hnRNP K, hnRNP H, Hsp90 $\alpha$, Grp78, and Hsp7C, which are associated with stress responses and mRNA processing. Several altered proteins were detected in multiple spots and had different molecular weights (Mws) and isoelectric points (PIs), including hnRNP K, $\beta$-actin, $\alpha$-tubulin 3, RGDI-2, and Hsp60 in Daudi cells (Table 1), and Hsp $\beta 1$ and hnRNP $\mathrm{K}$ in CA46 cells (Supplementary Table S1). In particular, different Mw forms of hnRNP K and RGDI-2 exhibited opposite changes in expression level in bortezomib-treated cells. In bortezomib-treated Daudi cells, the expression of RGDI-2 with a theoretical Mw of $23.0 \mathrm{kDa}$ and a calculated
Mw of $24.2 \mathrm{kDa}$ was upregulated; however, RGDI-2 with a calculated $\mathrm{Mw}$ of $26.7 \mathrm{kDa}$ was downregulated. Various Mw forms of hnRNP K (with a theoretical Mw of $51.0 \mathrm{kDa}$ ) were detected, which could be divided into a high-Mw $(\mathrm{HMw})$ group (of around $64 \mathrm{kDa}$ ) and a low-Mw $(\mathrm{LMw})$ group (of around $51 \mathrm{kDa}$ ). Interestingly, the $\mathrm{HMw}$ group was downregulated, while the LMw group was upregulated in bortezomib-treated Daudi and CA46 cells.

\section{Downregulation of sumoylated hnRNP $\mathrm{K}$ in bortezomib-treated cells}

To confirm the expression profile of hnRNP K obtained from the proteomic analysis, we treated Daudi cells with bortezomib and performed western blot analysis. As shown in Fig. 3, bortezomib treatment significantly decreased $\mathrm{HMw}$ but increased LMw hnRNP $\mathrm{K}$ protein expression in time- and dose-dependent manners. Previous studies have demonstrated that multiple post-translational modifications such as phosphorylation, methylation, ubiquitination, and sumoylation, may occur in hnRNP K $[25,26]$. Most SUMO proteins are approximately $12 \mathrm{kDa}$ in mass, which matched the difference between the HMw and LMw forms of hnRNP $\mathrm{K}$. To ascertain hnRNP K sumoylation, we performed immunoprecipitation with an anti-hnRNP K antibody followed by immunoblotting with an anti-pan-SUMO antibody. As shown in Fig. 4A, sumoylated hnRNP K was detected in control Daudi cells, but it had decreased in bortezomib-treated cells. To confirm these findings, we performed immunoprecipitation with an anti-SUMO-1 or anti-pan-SUMO antibody followed by immunoblotting with an anti-hnRNP $\mathrm{K}$ antibody. The results verified 
Table 1: List of significant altered protein identified by MALDI-Q-TOF in bortezomib-treated Daudi cells

\begin{tabular}{|c|c|c|c|c|c|}
\hline $\begin{array}{l}\text { Protein name } \\
\text { (Calculates kDa, PI) }\end{array}$ & $\begin{array}{l}\text { SWISS- } \\
\text { PROT } \\
\text { number }\end{array}$ & $\begin{array}{l}\text { Mascot } \\
\text { score }\end{array}$ & Change folds & Cellular location & Molecular function \\
\hline $\begin{array}{l}14-3-3 \beta / \alpha \\
(28.5,4.73)\end{array}$ & P31946 & 56 & +95.32 & $\begin{array}{l}\text { Cytoplasm, } \\
\text { melanosome }\end{array}$ & $\begin{array}{l}\text { Ras protein signal } \\
\text { transduction, apoptosis }\end{array}$ \\
\hline PRDX6 $(23.8,5.65)$ & P30041 & 89 & +74.21 & Cytoplasm, lysosome & $\begin{array}{l}\text { Antioxidant activity, } \\
\text { redox regulation }\end{array}$ \\
\hline $\begin{array}{l}\text { hnRNP K }(51.0,5.99 \\
50.0,6.30)\end{array}$ & P61978 & $39 ; 90$ & $+62.77 ;+19.92$ & Cytoplasm, nucleus & $\begin{array}{l}\text { hnRNP, mRNA } \\
\text { processing }\end{array}$ \\
\hline hnRNP H $(57.0,6.08)$ & P31943 & 315 & +40.00 & Nucleus, nucleoplasm & $\begin{array}{l}\text { hnRNP, mRNA } \\
\text { processing }\end{array}$ \\
\hline RGDI-2 $(24.2,6.88)$ & P52566 & 73 & +20.17 & Cytoplasm & $\begin{array}{l}\text { Regulates the GDP/ } \\
\text { GTP exchange }\end{array}$ \\
\hline $\operatorname{LamR}(44.6,4.70)$ & P08865 & 67 & +14.74 & Cytoplasm & $\begin{array}{l}\text { Translational } \\
\text { elongation, cell } \\
\text { adhesion }\end{array}$ \\
\hline eIF4A-I $(49.7,5.59)$ & P60842 & 186 & +10.89 & Cytoplasm & Protein biosynthesis \\
\hline $\begin{array}{l}\beta \text {-actin }(47.1,5.98 ; \\
43.9,5.96 ; 46.7,5.82)\end{array}$ & P60709 & $\begin{array}{l}89 ; 101 \\
249\end{array}$ & $+10.88 ;+5.98 ;+3.02$ & $\begin{array}{l}\text { Cytoplasm, } \\
\text { cytoskeleton }\end{array}$ & $\begin{array}{l}\text { Structural protein, cell } \\
\text { motility }\end{array}$ \\
\hline $\begin{array}{l}\text { hnRNP C1/C2 } \\
(41.7,5.28)\end{array}$ & P07910 & 124 & +8.06 & Nucleus & $\begin{array}{l}\text { hnRNP, mRNA } \\
\text { processing }\end{array}$ \\
\hline $\begin{array}{l}\alpha \text {-tubulin } 3(57.2, \\
5.40 ; 57.6,5.33)\end{array}$ & Q71U36 & $228 ; 233$ & $+6.33 ;+3.07$ & Cytosteleton & Microtubules \\
\hline Hsp90 $\alpha(96.1,4.91)$ & P07900 & 112 & +5.24 & $\begin{array}{l}\text { Cytoplasm, } \\
\text { melanosome }\end{array}$ & $\begin{array}{l}\text { Stress response, } \\
\text { chaperone }\end{array}$ \\
\hline Grp78 $(80.6,4.96)$ & P11021 & 237 & +3.71 & Endoplasmic reticulum & $\begin{array}{l}\text { Stress response, } \\
\text { anti-apoptosis }\end{array}$ \\
\hline Hsp7C (74.5, 5.39) & P11142 & 102 & +2.86 & $\begin{array}{l}\text { Cytoplasm, } \\
\text { melanosome }\end{array}$ & $\begin{array}{l}\text { Stress response, } \\
\text { chaperone }\end{array}$ \\
\hline $14-3-3 \varepsilon(28.5,4.67)$ & P62258 & 83 & +2.29 & $\begin{array}{l}\text { Cytoplasm, } \\
\text { melanosome }\end{array}$ & $\begin{array}{l}\text { Adapter protein, } \\
\text { intracellular signaling }\end{array}$ \\
\hline TDP-43 (49.1, 6.05) & Q13148 & 160 & -2.33 & Nucleus & $\begin{array}{l}\text { Transcription } \\
\text { regulation, mRNA } \\
\text { processing }\end{array}$ \\
\hline RGDI-2 $(26.7,5.10)$ & P52566 & 128 & -2.50 & Cytoplasm & $\begin{array}{l}\text { Regulates the GDP/ } \\
\text { GTP exchange }\end{array}$ \\
\hline $\begin{array}{l}\text { Hsp60 (63.8, 5.21; } \\
64.1,5.36)\end{array}$ & P10809 & $90 ; 299$ & $-2.95 ;-3.45$ & Mitochondrion matrix & $\begin{array}{l}\text { Chaperone, regulation } \\
\text { of apoptosis }\end{array}$ \\
\hline hnRNP F $(52.4,5.41)$ & P52597 & 99 & -3.21 & Nucleus, nucleoplasm & $\begin{array}{l}\text { hnRNP, mRNA } \\
\text { processing }\end{array}$ \\
\hline RPLP0 $(39.9,5.67)$ & P05388 & 92 & -3.57 & Ribonucleoprotein & Translational elongation \\
\hline $\begin{array}{l}\text { hnRNP K }(64.5,5.12 ; \\
64.2,5.51)\end{array}$ & P61978 & $65 ; 52$ & $-3.70 ;-2.38$ & Cytoplasm, nucleus & $\begin{array}{l}\text { hnRNP, mRNA } \\
\text { processing }\end{array}$ \\
\hline PA28g $(33.6,5.83)$ & P61289 & 260 & -5.88 & Proteasome & $\begin{array}{l}\text { Immunoproteasome } \\
\text { assembly }\end{array}$ \\
\hline
\end{tabular}




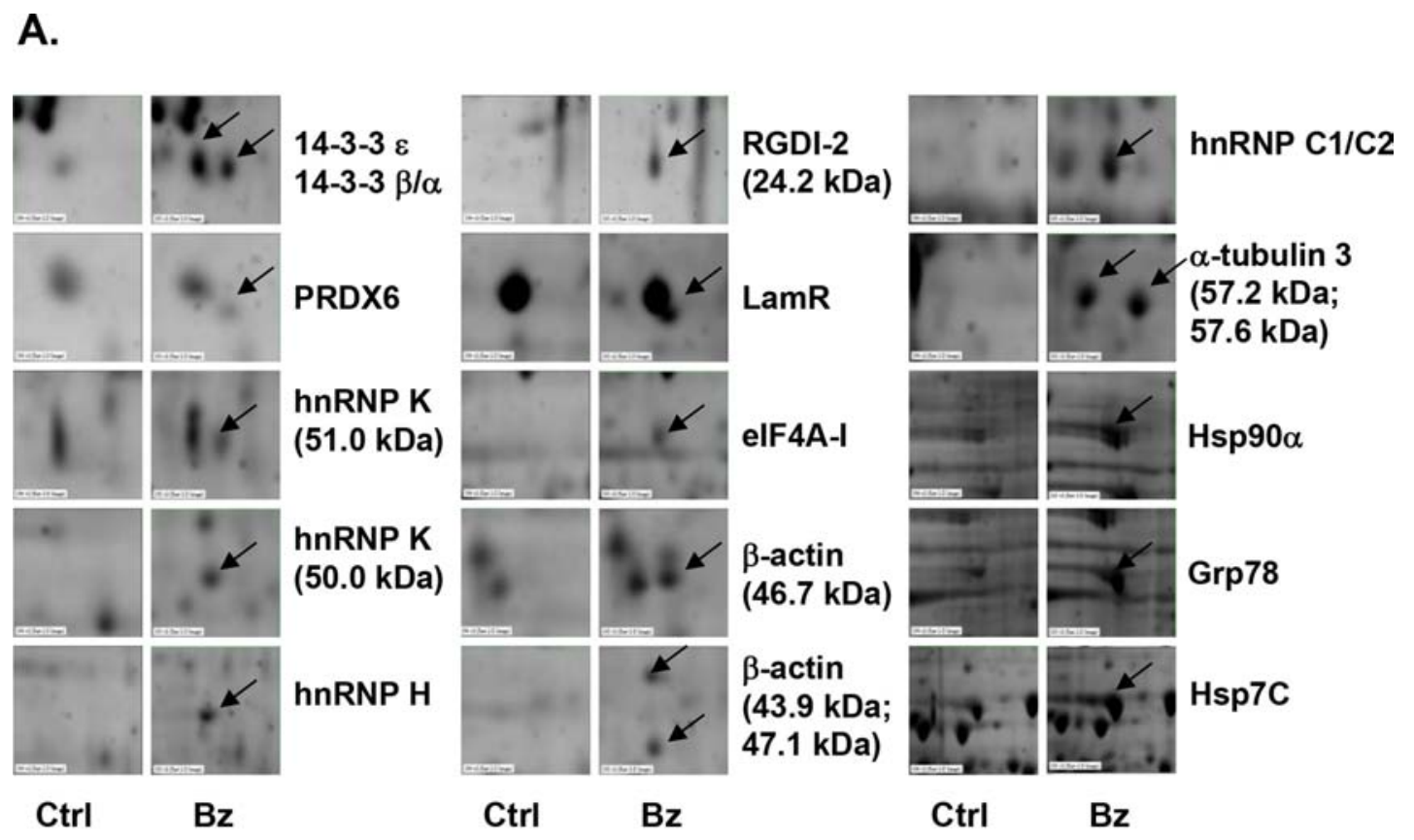

B.
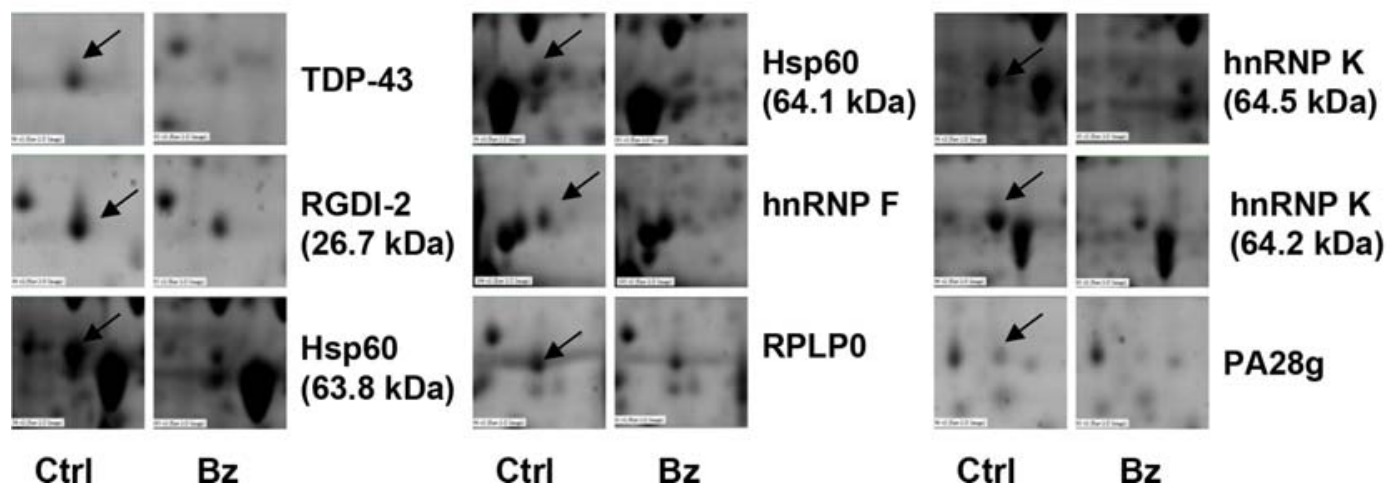

Figure 2: Proteomic analysis of altered proteins in bortezomib-treated human Burkitt's lymphoma cells. Daudi cells were treated with $10 \mathrm{nM}$ bortezomib $(\mathrm{Bz})$ for $12 \mathrm{~h}$, total cellular proteins were subjected to two-dimensional electrophoresis, and altered proteins were identified by MALDI-Q-TOF. A. Upregulated and B. downregulated proteins. Ctrl, control.

that sumoylated hnRNP K was present in control Daudi cells, but decreased in bortezomib-treated cells. Next, we investigated whether the $\mathrm{HMw}$ band (of around $64 \mathrm{kDa}$ ) in Fig. 3 represented sumoylated hnRNP K. Daudi cells were transiently transfected with pcDNA 3 control plasmid or SUMO-1 expression plasmid and then treated with or without bortezomib. As shown in Fig. 4B, the HMw band was stained by the hnRNP K and pan-SUMO antibodies, and the staining was weaker in bortezomib-treated cells. Transfection of the cells with the Sra-HA-SUMO-1 plasmid increased the expression of HMw hnRNP K in a dose-dependent manner as indicated by immunoblotting with hnRNP K and SUMO-1 antibodies (Fig. 4C). Since the HMw band represented sumoylated hnRNP K, the SUMO molecules should be removed by SENP. As shown in Fig. 4D, overexpression of wild-type SENP2 significantly decreased expression of HMw hnRNP K, while overexpression of mutant SENP2 did not. These results suggested that hnRNP K sumoylation is a general event in human Burkitt's lymphoma cells, and bortezomib decreases expression of sumoylated hnRNP K.

\section{Sumoylated hnRNP K and c-Myc expression are associated with proliferation of Burkitt's lymphoma cells}

Burkitt's lymphoma cells highly express the $c-M y c$ oncogene [5], which is upregulated by hnRNP $\mathrm{K}$ both at the level of transcription and translation $[27,28]$. To investigate whether expression of sumoylated hnRNP K and c-Myc is correlated with cell proliferation, we cultured Daudi cells in different nutrient conditions. Cells were either supplemented with serum to stimulate cell proliferation or deprived of serum to 


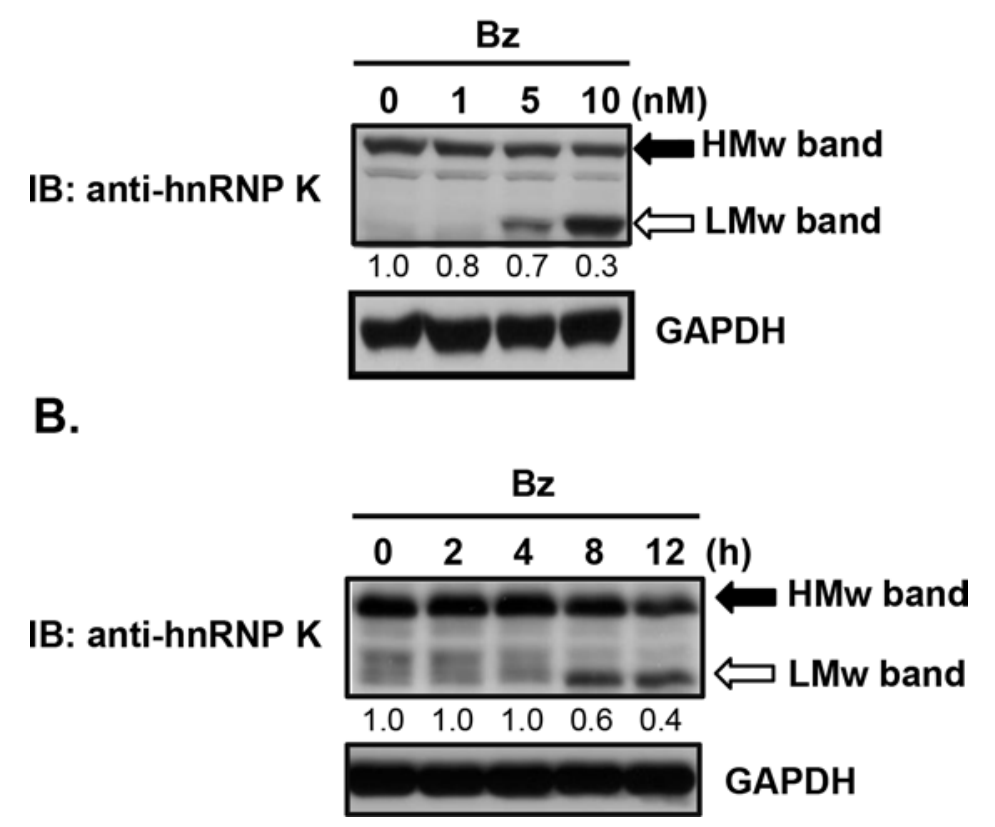

Figure 3: Changes in high- and low-molecular-weight hnRNP K protein expression in bortezomib-treated human Burkitt's lymphoma cells. (A, B) Daudi cells were treated with A. various concentrations of bortezomib (Bz) for $12 \mathrm{~h}$, or B. $10 \mathrm{nM}$ bortezomib for the indicated periods. Total cellular proteins were collected to detect protein expression by western blotting. HMw, highmolecular-weight; LMw, low-molecular-weight. The numbers below the lanes indicate the relative intensities of HMw to control (defined as 1.0) proteins.

limit cell proliferation for different periods. As shown in Fig. 5, expression of sumoylated hnRNP K and c-Myc increased in a time-dependent manner in cells treated with serum; however, expression of sumoylated hnRNP K and c-Myc decreased under serum deprivation. These results suggested that sumoylated hnRNP K and c-Myc may be involved in regulating the proliferation of Daudi cells.

\section{c-Myc is upregulated by sumoylated hnRNP K at the translational level in Burkitt's lymphoma cells}

To investigate whether c-Myc is regulated by sumoylated hnRNP K, we examined the mRNA and protein levels of c-Myc in bortezomib-treated cells. As shown in Fig. 6, bortezomib treatment decreased the c-Myc protein, but not the mRNA level, in dose- and time-dependent manners in Daudi cells, suggesting that c-Myc expression is regulated at the translational level. Previous studies have demonstrated that hnRNP K upregulates c-Myc expression at the translational level, where hnRNP K is bound to the internal ribosome entry sequence (IRES) region of c-Myc mRNA and increases c-Myc protein expression [28]. To investigate whether sumoylated hnRNP K upregulates c-Myc protein expression, we transiently transfected Daudi cells with the pGL3-Myc-5' UTR-Luc reporter plasmid that contains human c-Myc IRESs and a partial c-Myc 5' non-coding region before the firefly luciferase reporter gene
(Fig. 7A). Bortezomib treatment significantly decreased the luciferase activity in a dose-dependent manner (Fig. 7B). Overexpression of SUMO-1 increased the luciferase activity; however, overexpression of SENP1 and SENP2 decreased the expression of sumoylated hnRNP K and luciferase activity (Fig. 7C). In addition, overexpression of hnRNP $\mathrm{K}$ and SUMO-1 significantly increased cell proliferation ( $\sim 1.46$-fold), while treatment with bortezomib decreased the cell proliferation induced by hnRNP K and SUMO-1 (Fig. 7D). These results suggested that c-Myc expression is upregulated by sumoylated hnRNP $\mathrm{K}$ at the translational level, and that sumoylated hnRNP K contributes to cell proliferation.

\section{Lys422 may be the major sumoylation site in hnRNP K}

To predict the potential sumoylation sites in hnRNP K, we used the SUMOplot Analysis Program (http://www.abgent.com/sumoplot). Among seven potential sumoylation sites, Lys 422 had the highest score (0.94) and, therefore, was considered the major sumoylation site (Fig. 8A). To verify this hypothesis, a mutant hnRNP K (Arg422) expression plasmid was constructed. As shown in Fig. 8B, overexpression of mutant hnRNP $\mathrm{K}$ resulted in a decrease in sumoylated hnRNP K, suggesting that Lys422 may be the major sumoylation site in hnRNP K. 

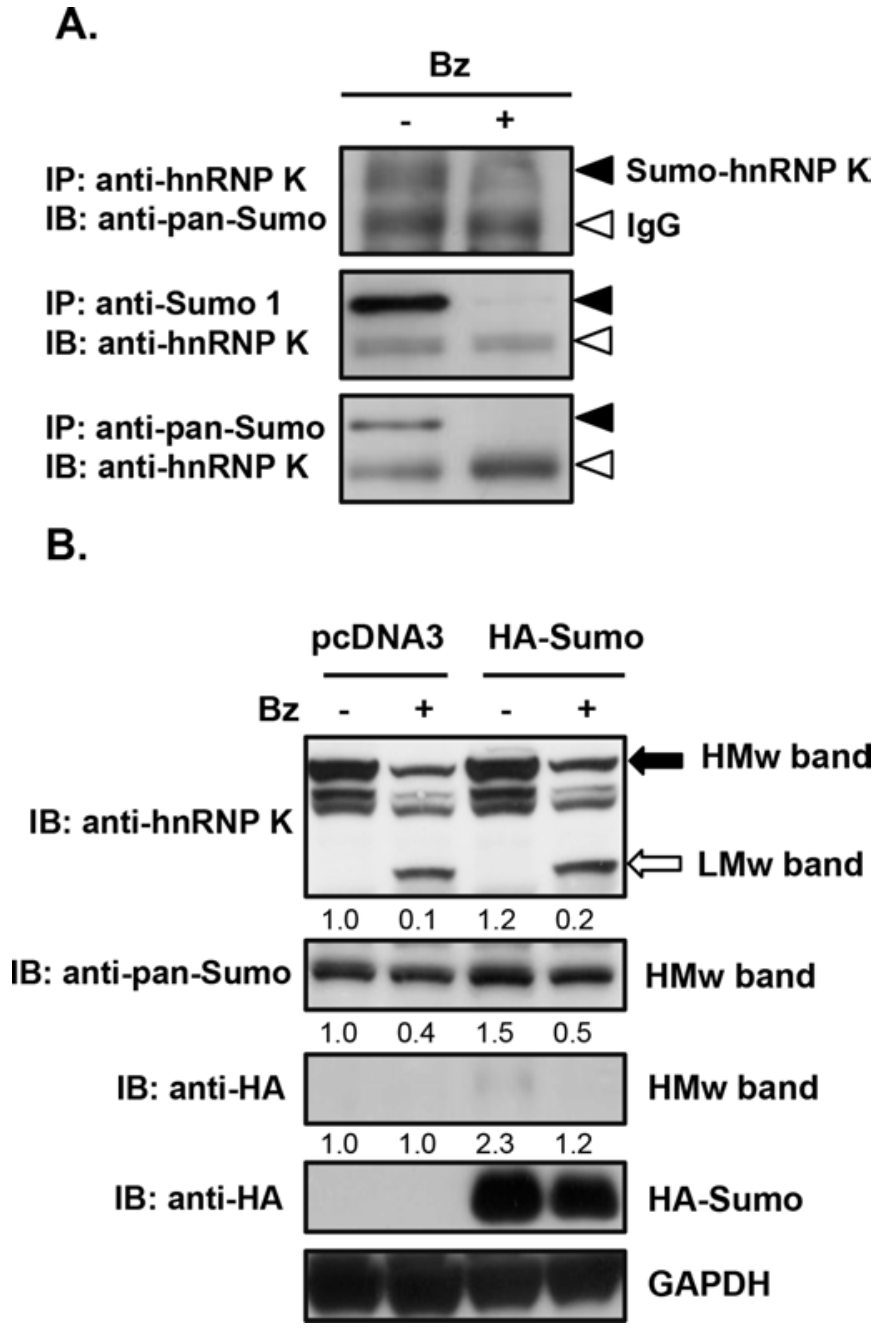

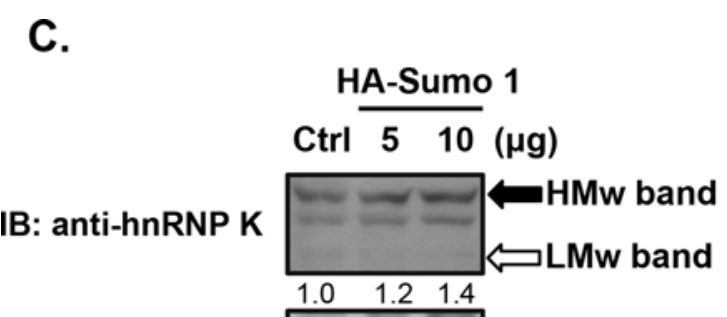

IB: anti-Sumo 1

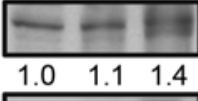

HMw band

IB: anti-Sumo 1

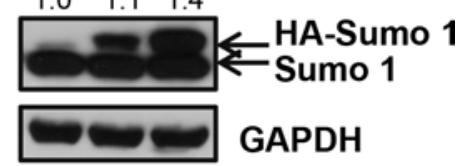

D.

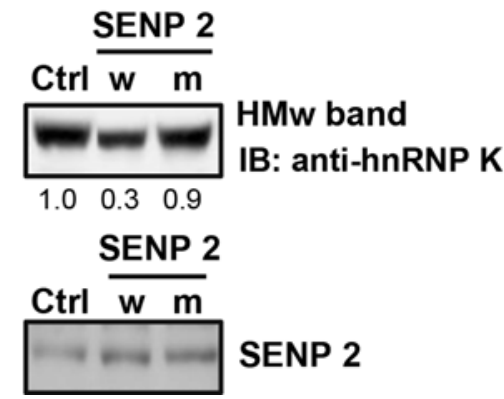

Figure 4: Downregulation of sumoylated hnRNP K expression in bortezomib-treated human Burkitt's lymphoma cells. A. Daudi cells were treated with $10 \mathrm{nM}$ bortezomib (Bz) for $12 \mathrm{~h}$. Total cellular proteins were collected to detect protein expression by immunoprecipitation (IP) and immunoblotting (IB). Solid arrowhead, sumoylated hnRNP K (Sumo-hnRNP K); open arrowhead, heavy chain of the IgG antibody (IgG). B. Daudi cells were transfected with the control plasmid (pcDNA 3) or the SRa-HA-SUMO plasmid (HA-Sumo) by electroporation. After $48 \mathrm{~h}$ of transfection, the cells were treated with $10 \mathrm{nM}$ bortezomib for $12 \mathrm{~h}$, and total cellular proteins were collected to detect protein expression by western blotting. C. Daudi cells were transfected with 5 and $10 \mu \mathrm{g}$ of the SRaHA-SUMO plasmid (HA-Sumo) by electroporation. After $48 \mathrm{~h}$ of transfection, total proteins were collected to detect protein expression by western blotting. D. Daudi cells were transfected with wild-type (w) and mutant (m) plasmids of SENP2 by electroporation. After $48 \mathrm{~h}$ of transfection, total proteins were collected to detect protein expression by western blotting. HMw, high-molecular-weight; LMw, low-molecular-weight. The numbers below the lanes indicate the relative intensities of $\mathrm{HMw}$ to control (defined as 1.0) proteins.

\section{DISCUSSION}

In this study, different Mw forms of hnRNP K were observed in bortezomib-treated Burkitt's lymphoma cells. The HMw and LMw forms of hnRNP $\mathrm{K}$ were approximately $64 \mathrm{kDa}$ and $51 \mathrm{kDa}$, respectively. Further analysis indicated that the $\mathrm{HMw}$ form was sumoylated hnRNP $\mathrm{K}$ and that Lys422 might have been the sumoylation site. Previous studies have indicated that several hnRNP family proteins such as hnRNP A1, hnRNP $\mathrm{F}$, and hnRNP K can be sumoylated, which may regulate mRNA metabolism [25]. Overexpression of SUMO-1 increased the protein expression of $\sim 38-\mathrm{kDa} h n R N P$
A2/B1 and $~ 50-k D a$ hnRNP A2/B1 in HepG2 cells [34]. Based on western blot results and SUMOplot predictions, a $\sim 50-k D a$ form of hnRNP A2/B1 has been considered to be the sumoylated, which may have protected the protein from degradation by the ubiquitin-proteasome pathway [34]. Because the SUMO and ubiquitin modifications occurred at the same Lys residue of the target protein, they would be in competition. Similar to hnRNP A2/B1, sumoylation of hnRNP K might have protected it from degradation. In agreement with this hypothesis, normal cultured cells expressed large amounts of HMw hnRNP $\mathrm{K}$, but barely expressed LMw hnRNP K. Bortezomib decreased the expression of $\mathrm{HMw}$ hnRNP $\mathrm{K}$ and 

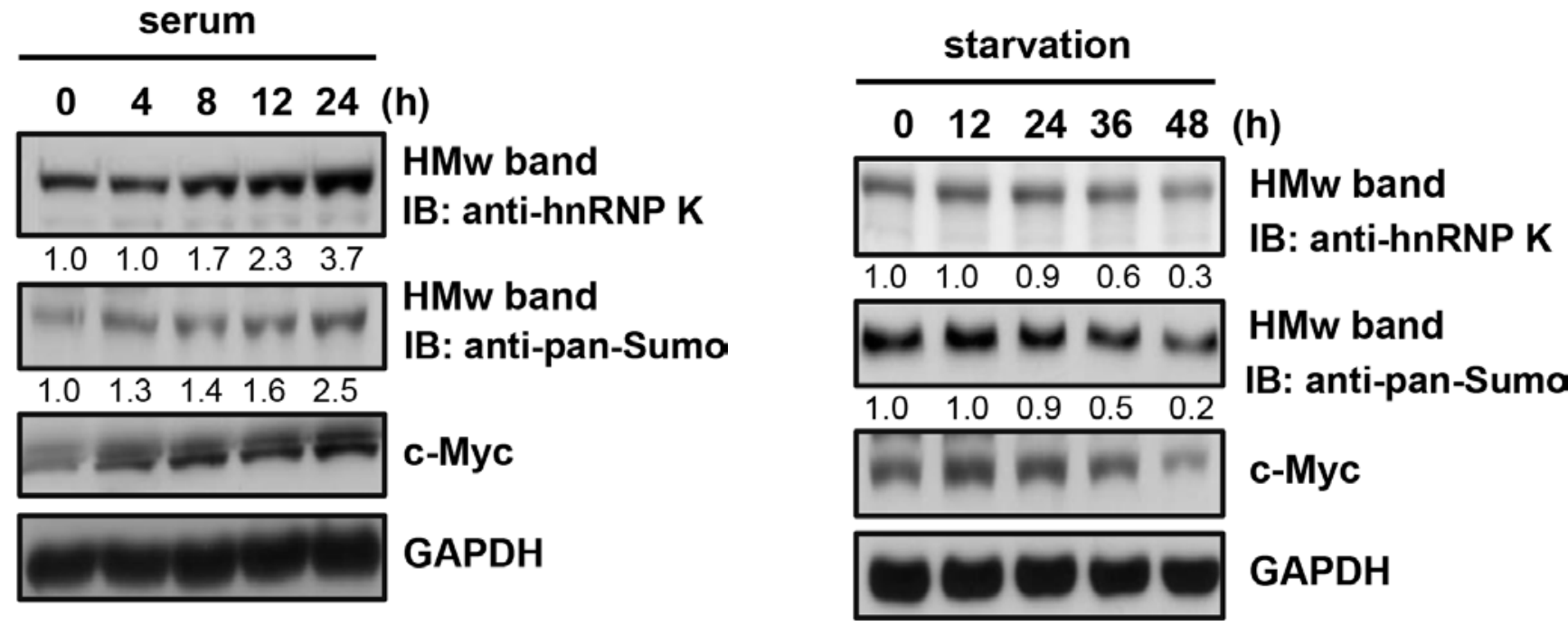

Figure 5: Effects of nutrition and starvation on the protein expression of sumoylated hnRNP K and c-Myc in human Burkitt's lymphoma cells. A. Daudi cells were starved for $24 \mathrm{~h}$ and then treated with $10 \%$ fetal bovine serum (FBS) for the indicated periods. B. Daudi cells were starved for the indicated periods. Total cellular proteins were collected to detect protein expression by western blotting. HMw, high-molecular-weight; LMw, low-molecular-weight. The numbers below the lanes indicate the relative intensities of HMw to control (defined as 1.0) proteins.

A.

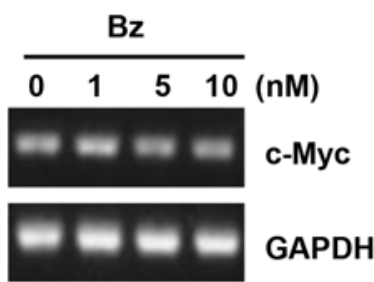

B.

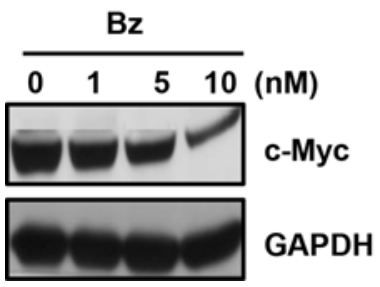

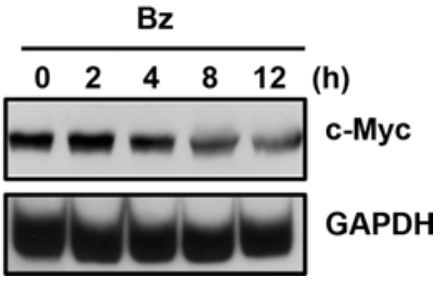

Figure 6: Downregulation of c-Myc protein expression in bortezomib-treated human Burkitt's lymphoma cells. (A, B) Daudi cells were treated with various concentrations of bortezomib (Bz), or with $10 \mathrm{nM}$ bortezomib for the indicated periods. A. Total RNA was extracted to detect mRNA expression by RT-PCR, and B. total cellular proteins were collected to detect protein expression by western blotting.

increased the expression of LMw hnRNP $\mathrm{K}$. These results suggested that the increase in LMw hnRNP $\mathrm{K}$ in response to bortezomib might be mediated by protection of hnRNP K from ubiquitin-proteasome degradation or by desumoylation of sumoylated hnRNP K. Sumoylation of hnRNP C and hnRNP M facilitated nucleocytoplasmic transport of mRNAs and decreased their binding to nucleic acids [35]. However, we demonstrated that sumoylated hnRNP K increased the translational activity of Myc 5' UTR IRES, suggesting that sumoylation promotes binding of hnRNP K to the IRES nucleic acid segment, in contrast to hnRNP C.

Similar to ubiquitin, SUMO can attach to proteins as a single entity at one or multiple sites, to form mono- and multi-monosumoylated proteins, respectively [36]. In contrast, polysumoylation is the formation of a SUMO chain on target proteins. Monosumoylation is the major type of SUMO modification. In addition to the 64- and 51-kDa forms of hnRNP K, several other HMw bands were detected when the film was exposed for a longer time, which showed altered expression after bortezomib treatment (Supplementary Fig. S1, arrowheads). Similar findings were obtained with another proteasome inhibitor, MG132; treatment with MG132 altered the expression of different $\mathrm{Mw}$ forms of hnRNP $\mathrm{K}$. These results suggested that endogenous hnRNP $\mathrm{K}$ might exist as multiple sumoylated forms, and that inhibition of proteasome activity might promote desumoylation of hnRNP K.

hnRNP $\mathrm{K}$ regulates protein expression at both the transcriptional and translational levels. At 
A.

\begin{tabular}{|l|l|l|l|l|l|}
$\begin{array}{ll}\text { SV40 } \\
\text { promoter }\end{array}$ & $\begin{array}{l}\text { C-Myc } \\
\text { 5' IRES }\end{array}$ & Firefly luciferase gene & $\begin{array}{l}\text { SV40 } \\
\text { poly A }\end{array}$ & $\begin{array}{l}\text { SV40 } \\
\text { enhancer }\end{array}$ \\
\hline
\end{tabular}

B.

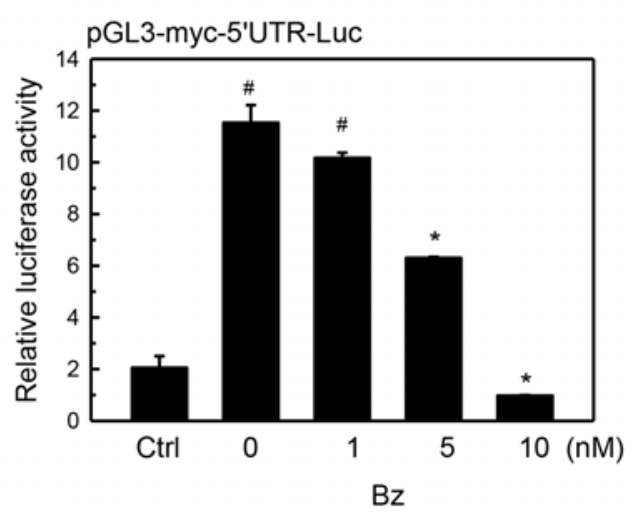

C.

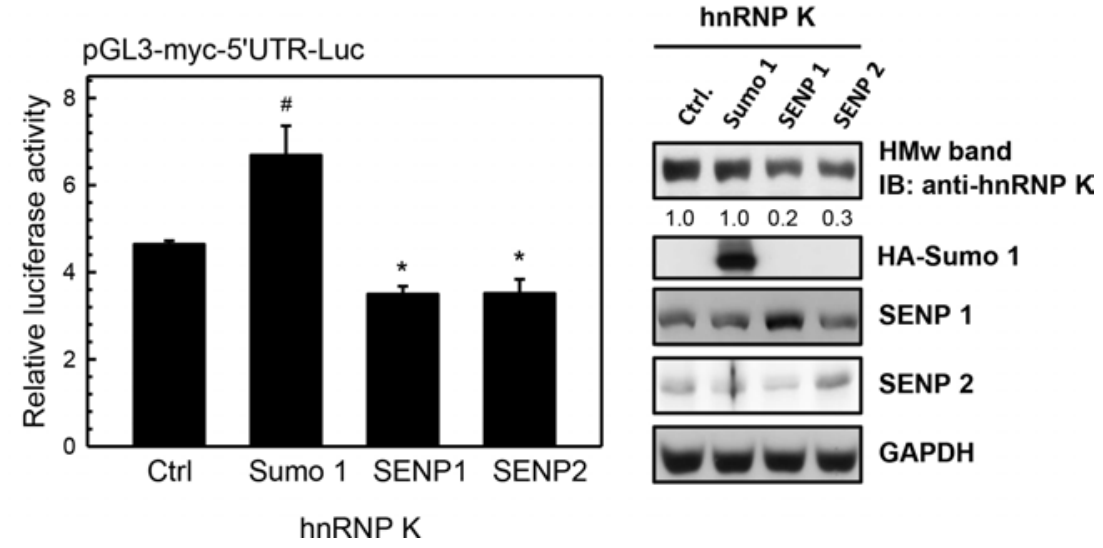

D.
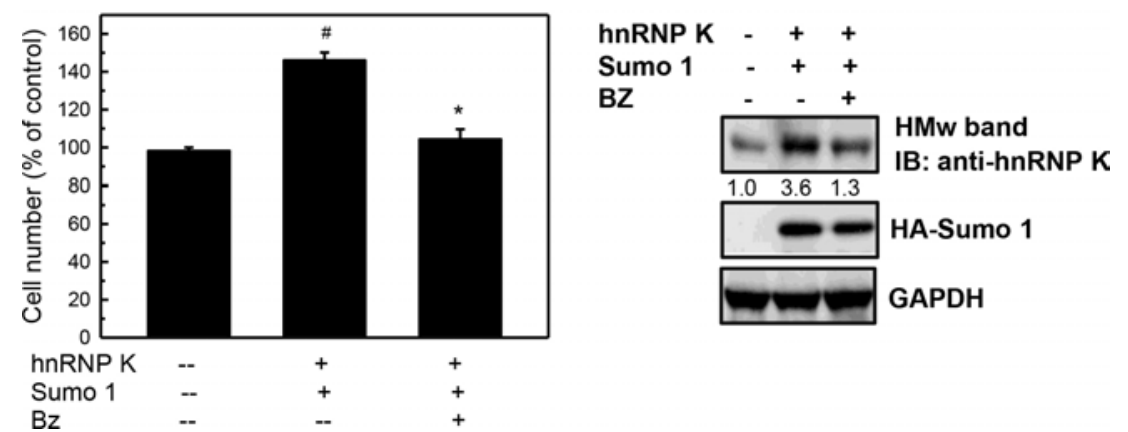

Figure 7: Upregulation of c-Myc protein expression by sumoylated hnRNP K in human Burkitt's lymphoma cells. A. Schematic representation of the configuration of the pGL3-Myc-5' UTR-Luc reporter plasmid. B. Daudi cells were transfected with $10 \mu \mathrm{g}$ of the pGL3-Myc-5' UTR-Luc reporter plasmid and the purl-TK plasmid (as an internal control) by electroporation. After $36 \mathrm{~h}$ of transfection, the cells were treated with various concentrations of bortezomib $(\mathrm{Bz})$ for $12 \mathrm{~h}$. Total cell lysates were collected to detect luciferase activities as described in "Materials and Methods". C. Daudi cells were transfected with either SRa-HA-SUMO-1, Flag-SENP1, or Flag-SENP2 and hnRNP K as well as pGL3-Myc-5' UTR-Luc and phRL-TK (as an internal control) by electroporation. After $48 \mathrm{~h}$ of transfection, total cell lysates were collected to detect luciferase activities as described in "Materials and Methods" and to analyze protein expression by western blotting. D. Daudi cells were transfected with hnRNP K and SRa-HA-SUMO-1 by electroporation. After $36 \mathrm{~h}$ of transfection, the cells were treated with $5 \mathrm{nM}$ bortezomib (Bz) for $12 \mathrm{~h}$ and the viable cells were determined by MTT assay. Values are presented as the mean \pm S.E. of triplicate tests. ${ }^{*} p<0.05$ vs. lane $1 ;{ }^{*} p<0.05$ vs. lane 2 . HMw, high-molecular-weight. 


\begin{tabular}{lcc} 
A. \\
\multicolumn{3}{l}{} \\
\hline No. & Position & Score \\
\hline 1 & K422 & 0.94 \\
2 & K198 & 0.67 \\
3 & K179 & 0.59 \\
4 & K21 & 0.57 \\
5 & K405 & 0.50 \\
6 & K60 & 0.50 \\
7 & K461 & 0.32 \\
\hline
\end{tabular}

B.

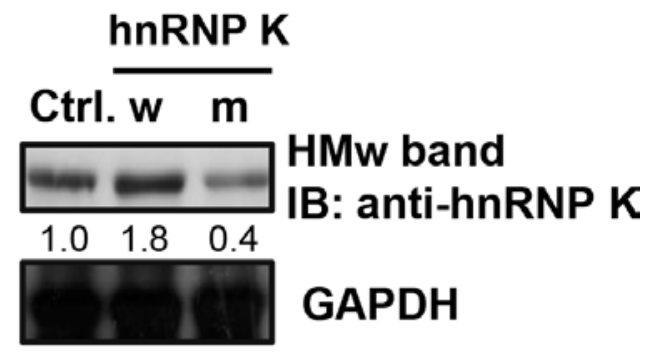

Figure 8: Lysine 422 is the potential sumoylation site in human hnRNP K. A. The possible sumoylation sites of hnRNP K and the scores predicted by the SUMOplot Analysis Program. B. Daudi cells were transfected with the wild-type hnRNP K (w) or hnRNP K K422R mutant $(\mathrm{m})$ plasmids by electroporation. After $48 \mathrm{~h}$ of transfection, total cell lysates were collected to detect protein expression by western blotting. HMw, high-molecular-weight. The numbers below the lanes indicate the relative intensities of HMw to control (defined as 1.0$)$ proteins.

the transcriptional level, hnRNP $\mathrm{K}$ can bind to the poly $(\mathrm{C})$ region of promoters of genes including $c-S r c$, eIF4E, and $c-M y c[37,38]$. In addition, hnRNP K can increase FLIP expression by binding to the $\operatorname{poly}(\mathrm{C})$ region of its promoter, leading to inhibition of tumor necrosis factor-related apoptosis-inducing ligand (TRAIL)-induced apoptosis [39]. Apart from regulating mRNA transcription rates, hnRNP $\mathrm{K}$ has been found to bind to various specific mRNA sequences and to regulate their translation activities. Chen et al. demonstrated that hnRNP K increased thymidine phosphorylase (TP) mRNA stability and protein translation by directly interacting with the CU-rich element of TP mRNA [40]. Another study showed binding of hnRNP K to the $3^{\prime}$ UTR differentiation control element (DICE) of 15-lipoxygenase (LOX) mRNA, which resulted in inhibition of LOX mRNA translation [41]. Moreover, hnRNP K upregulated c-Myc protein expression by binding to the 5' UTR IRES of c-Myc mRNA [28]. hnRNP A1 was phosphorylated upon interleukin (IL)-6 stimulation, which increased Myc protein translation by binding to the IRES of Myc mRNA in multiple myeloma cells [42]. In this study, bortezomib decreased both sumoylated hnRNP K and c-Myc protein, but it did not change the c-Myc mRNA level. Using the pGL3-Myc-5' UTR-Luc reporter plasmid that contains human c-Myc IRESs, we found that sumoylated hnRNP Kincreased the reporter activity, while desumoylated hnRNP K did not. These results suggested that hnRNP K regulates c-Myc expression at the translational level, and sumoylation plays an important role in binding of hnRNP Kto the IRES of c-Myc mRNA.

Recent studies have revealed that c-Myc overexpression indicates poor prognosis in multiple myelomas [43]. Our finding that bortezomib inhibits
c-Myc expression might increase our understanding of the action mechanisms of bortezomib in clinical therapies of multiple myelomas and why multiple c-Myc-overexpressing myelomas respond differently to bortezomib compared to dexamethasone [44]. We found that sumoylated hnRNP K positively regulates c-Myc expression, which contributed to cell proliferation. Previous studies have indicated that combined treatment with bortezomib and other drugs such as anti- $\beta 2$-microglobulin monoclonal antibody [45] and the DNA methyltransferase inhibitor decitabine [46] overcomes bortezomib drug resistance in multiple myeloma and mantle cell lymphoma, respectively. Therefore, treatment with sumoylation inhibitors alone or in combination with bortezomib may be useful in novel therapeutic strategies for multiple myelomas and Burkitt's lymphoma in future.

\section{MATERIALS AND METHODS}

\section{Materials}

Bortezomib was purchased from JanssenCilag (Buckinghamshire, UK) and was dissolved in dimethyl sulfoxide (DMSO). Anti-hnRNP K antibody was purchased from Cell Signaling Technology (New England Biolabs, Schwalbach, Germany) and Santa Cruz Biotechnology (Santa Cruz, Dallas, TX), anti-pan-SUMO, anti-SUMO-1, anti-SENP1, and anti-SENP2 antibodies were purchased from Abcam (Cambridge, MA), anti-c-Myc and anti-HA antibodies were purchased from Cell Signaling Technology, and anti-GAPDH antibody was purchased from GeneTex (Irvine, CA). 


\section{Cell culture and viability assay}

Human Burkitt's lymphoma CA46 (BCRC 60511) and Daudi (BCRC 60192) cells were obtained from the Food Industry Research and Development Institute (Hsinchu, Taiwan). Both cell lines were cultured in RPMI-1640 medium supplemented with $10 \%$ heat-inactivated fetal bovine serum (FBS, Life Technologies, Grand Island, NY), and maintained in a humidified incubator at $37^{\circ} \mathrm{C}$ with $5 \% \mathrm{CO}_{2}$. CA46 and Daudi cells were cultured in 6-well plates and treated with various concentrations of bortezomib for $24 \mathrm{~h}$, and the cell viability was determined by the 3-(4, 5)-dimethylthiahiazo(-z-y1)-3, 5-diphenytetrazoliumromide (MTT, Sigma Chemical, St. Louis, MO) assay as described previously [47].

\section{Western blotting}

Total cellular proteins $(30-50 \mu \mathrm{g})$ were fractionated by sodium dodecylsulfate-polyacrylamide gel electrophoresis (SDS-PAGE). After the proteins had been transferred onto a polyvinylidene difluoride membrane (Merck Millipore, Billerica, MA), the membrane was blocked in $1 \%$ bovine serum albumin (BSA) or 10\% defatted milk for $1 \mathrm{~h}$ before incubation with the primary antibodies overnight at $4^{\circ} \mathrm{C}$. Antigen-antibody complexes were detected using secondary antibodies conjugated to horseradish peroxidase (HRP) and visualized using enhanced chemiluminescence (ECL; GE Healthcare, Piscataway, NJ) [48].

\section{Reverse transcription-polymerase chain reaction (RT-PCR)}

Total RNA was isolated from cultured cells and complementary (c)DNA was prepared as described previously [49]. c-Myc and glyceraldehyde-3-phosphate dehydrogenase (GAPDH) cDNAs were amplified in reactions mixtures comprising $500 \mathrm{ng}$ of total cDNA in $100 \mathrm{mM}$ Tris- $\mathrm{HCl}$ buffer (at $\mathrm{pH}$ 8.3) containing $500 \mathrm{mM} \mathrm{KCl}, 15 \mathrm{mM} \mathrm{MgCl}, 0.1 \%$ gelatin, $200 \mu \mathrm{M}$ of each dNTP, and 50 units $/ \mathrm{mL}$ of SuperTaq ${ }^{\mathrm{TM}}$ DNA polymerase (Ambion, Austin, TX) and the following oligonucleotide primers: 5'-AGCCCACTGGTCCTCAAGA-3' and 5'-CCTCTTACAGTTCTCCGCTTG-3' for c-Myc, and 5'-TGAAGGTCGGTGTGAACGGATTTGGC-3' and 5'-CATGTAGGCCATGAGGTCCACCAC-3' for GAPDH. Thermal cycling conditions were as follows: $94^{\circ} \mathrm{C}$ for $5 \mathrm{~min}$, followed by 25 cycles at $94^{\circ} \mathrm{C}$ for $1 \mathrm{~min}, 50^{\circ} \mathrm{C}$ for $1 \mathrm{~min}$, and $72^{\circ} \mathrm{C}$ for $1 \mathrm{~min}$, and a final extension at $72^{\circ} \mathrm{C}$ for $8 \mathrm{~min}$. PCR products were separated on $1.2 \%$ agarose gels and stained with SYBR Green dye.

\section{Plasmids and transient transfection}

Gene expression plasmids SRa-HA-SUMO-1 (no. 17359), Flag-SENP1 (no. 17357), and Flag-SENP2 (no. 18047) were obtained from Addgene (Cambridge, MA).
The hnRNP K expression plasmid pCMV6-XL5-hnRNP $\mathrm{K}$ (sc107869) was purchased from OriGene Technologies (Rockville, MD), and the hnRNP K mutant (K422R) expression plasmid was obtained from Yeastern Biotech (New Taipei City, Taiwan). The pGL3-Myc-5' UTR-Luc reporter plasmid containing human c-Myc IRESs, a partial c-Myc $5^{\prime}$ non-coding region, and the firefly luciferase gene was generously provided by Professor Anne E. Willis (University of Nottingham, Nottingham, UK).

For gene overexpression, $5 \times 10^{6}$ cells were transiently transfected with $10 \mu \mathrm{g}$ of plasmid by electroporation at $1000 \mathrm{~V}$ for $40 \mathrm{~ms}$. For the reporter gene assay, cells were transiently transfected with the pGL3-Myc-5' UTR-Luc reporter plasmid and phRL-TK (Promega, Madison, WI) as an internal control plasmid as per the above conditions and then seeded in a 24well plate. Drug-treated cell lysates were collected, and luciferase activity was detected using the Dual-Luciferase ${ }^{\circledR}$ Reporter Assay System (Promega) and a Plate Chameleon Multilabel plate reader (HIDEX OY, Turku, Finland) according to the manufacturer's instructions. Luciferase activities of the reported plasmid were normalized to luciferase activities of the internal control plasmid [50].

\section{Two-dimensional electrophoresis and gel imaging}

Cells were lysed in solubilizing buffer (7 M urea, $4 \%$ CHAPS, and $2 \mathrm{M}$ thiourea; Amersham Biosciences, Piscataway, NJ) and total cell lysates were collected according to the manufacturer's instructions. Protein samples were added to an Immobiline ${ }^{\mathrm{TM}}$ DryStrip (pH 3-10,13 cm) (Amersham Biosciences), rehydrated at $50 \mu \mathrm{A} /$ strip and $30 \mathrm{~V}$ for $12 \mathrm{~h}$. Isoelectric focusing (IEF) electrophoresis was carried out using the Ettan IPGphor system (Amersham Biosciences) for another $12 \mathrm{~h}$. The linear voltage gradient conditions used were as follows: from 0 to $250 \mathrm{~V}$ for $250 \mathrm{Vh}, 500 \mathrm{~V}$ for $500 \mathrm{Vh}, 1000 \mathrm{~V}$ for $1000 \mathrm{Vh}, 1500 \mathrm{~V}$ for $1500 \mathrm{Vh}, 2000 \mathrm{~V}$ for $2000 \mathrm{Vh}$, $3000 \mathrm{~V}$ for $3000 \mathrm{Vh}, 6000 \mathrm{~V}$ for $6000 \mathrm{Vh}$, and a final phase of $8000 \mathrm{~V}$ for $40,000 \mathrm{Vh}$. Then, the Immobiline ${ }^{\mathrm{TM}}$ DryStrip was placed on a $10 \%$ sodium dodecylsulfate polyacrylamide gel and second-dimension electrophoresis was performed. The gels were fixed with $10 \%$ methanol and $7 \%$ acetic acid and stained with Sypro-Ruby dye (Sigma) for $3 \mathrm{~h}$.

Gel images were captured using a Typhoon 9400 densitometer and analyzed with PDQuest version 7.3.1 software (GE Healthcare). Protein spot detection and matching were performed by both automated function and manual designation. Spot intensities were obtained using the quantitative and qualitative modes and normalized to the background. Protein spot intensities with at least 2 -fold difference compared to the control were considered significantly different. Protein spots of interest were collected, gel-digested by trypsin, and subjected to MALDI-TOF/MS analysis. 


\section{Matrix-assisted laser desorption/ionization time-of-flight mass spectrometry (MALDI-TOF/ MS) and analysis of peptide sequences}

Selected protein spots were subjected to concerted MALDI peptide mass fingerprinting (PMF) and collision-induced dissociation (CID) MS/MS analysis for protein identification using a dedicated Q-Tof Ultima $^{\mathrm{TM}}$ MALDI instrument (Micromass, Manchester, UK). The instrument system was operated under MassLynx 4.0, and raw MS data were processed for database searching using ProteinLynx Global Server 2.0. All MS and MS/MS raw data were processed with Raw2MSM and searched against a target protein sequence database using the Mascot Daemon 2.2 server. Search criteria used were as follows: trypsin digestion; variable modifications set as carbamidomethyl (Cys) and oxidation (Met); up to two missed cleavages allowed; and a mass accuracy of $10 \mathrm{ppm}$ for the parent ion and $0.60 \mathrm{Da}$ for fragment ions.

\section{Statistical analysis}

All experiments were repeated at least three times. The statistical significance of differences was determined using Student's $t$-test in SPSS (IBM SPSS Statistics, Chicago, IL), with significance at $p<0.05$

\section{CONCLUSIONS}

We showed that several aspects of proteins can be regulated by bortezomib, in particular, it downregulated the expression of sumoylated hnRNP K and c-Myc in human Burkitt's lymphoma cells. Sumoylated hnRNP K positively regulated c-Myc expression at the translational level, and downregulation of sumoylated hnRNP K by bortezomib resulted in a decrease in c-Myc oncogene expression and subsequent inhibition of cell proliferation. The Lys422Arg mutation decreased the level of sumoylated hnRNP K, suggesting that hnRNP K can be modified by SUMO and that Lys422 might be an important sumoylation site in hnRNP K

\section{ACKNOWLEDGMENTS}

The proteomic mass spectrometry analyses were performed by the Core Facilities for Protein Structural Analysis located at the Institute of Biological Chemistry, Academia Sinica, and were supported by a grant (NSC100-2325-B-001-029) from the National Science Council, Taiwan. This work was supported by grants (NSC 98-2320-B-038-005-MY3 and NSC101-2320-B-038-017-MY3) from the National Science Council (Taipei, Taiwan, R.O.C.) and Wan Fang Hospital (103TMU-WFH-14).

\section{CONFLICTS OF INTEREST}

None.

\section{REFERENCES}

1. Hamrick-Turner JE, Saif MF, Powers CI, Blumenthal BI, Royal SA, Iyer RV. Imaging of childhood nonHodgkin lymphoma: assessment by histologic subtype. Radiographics. 1994; 14:11-28.

2. Magrath I. Epidemiology: clues to the pathogenesis of Burkitt lymphoma. Brit J Haematol. 2012; 156:744-756.

3. Molyneux EM, Rochford R, Griffin B, Newton R, Jackson G, Menon G, Harrison CJ, Israels T, Bailey S. Burkitt's lymphoma. Lancet. 2012; 379:1234-1244.

4. Tomita N. BCL2 and MYC dual-hit lymphoma/leukemia. J Clin Exp Hematop. 2011; 51:7-12.

5. Kenkre VP, Stock W. Burkitt lymphoma/leukemia: improving prognosis. Clin Lymphoma Myeloma. 2009; 9:S231-S238.

6. Wildes TM, Farrington L, Yeung C, Harrington AM, Foyil KV, Liu J, Kreisel F, Bartlett NL, Fenske TS. Rituximab is associated with improved survival in Burkitt lymphoma: a retrospective analysis from two US academic medical centers. Ther Adv Hematol. 2014; 5:3-12.

7. Kleiger G, Mayor T. Perilous journey: a tour of the ubiquitinproteasome system. Trends Cell Biol. 2014; 24:352-359.

8. Ye Y. The role of the ubiquitin-proteasome system in ER quality control. Essays Biochem. 2005; 41:99-112.

9. Cook C, Stetler C, Petrucelli L. Disruption of protein quality control in Parkinson's disease. Cold Spring Harb Perspect Med. 2012; 2:a009423.

10. Riederer BM, Leuba G, Vernay A, Riederer IM. The role of the ubiquitin proteasome system in Alzheimer's disease. Exp Biol Med (Maywood). 2011; 236:268-276.

11. Elliott PJ, Ross JS. The proteasome: a new target for novel drug therapies. Am J Clin Pathol. 2001; 116:637-646.

12. Richardson PG, Sonneveld P, Schuster MW, Irwin D, Stadtmauer EA, Facon T, Harousseau JL, Ben-Yehuda D, Lonial S, Goldschmidt H, Reece D, San-Miguel JF, Bladé J, et al. Bortezomib or high-dose dexamethasone for relapsed multiple myeloma. New Engl J Med. 2005; 352:2487-2498.

13. Chauhan D, Hideshima T, Mitsiades C, Richardson P, Anderson KC. Proteasome inhibitor therapy in multiple myeloma. Mol Cancer Ther. 2005; 4:686-692.

14. Hideshima T, Mitsiades C, Akiyama M, Hayashi T, Chauhan D, Richardson P, Schlossman R, Podar K, Munshi NC, Mitsiades N, Anderson KC. Molecular mechanisms mediating antimyeloma activity of proteasome inhibitor PS-341. Blood. 2003; 101:1530-1534.

15. Nawrocki ST, Carew JS, Dunner K Jr., Boise LH, Chiao PJ, Huang P, Abbruzzese JL, McConkey DJ. Bortezomib 
inhibits PKR-like endoplasmic reticulum (ER) kinase and induces apoptosis via ER stress in human pancreatic cancer cells. Cancer Res. 2005; 65:11510-11519.

16. Chauhan D, Bianchi G, Anderson KC. Targeting the UPS as therapy in multiple myeloma. BMC Biochem. 2008; 9:S1.

17. Ostrowski J, Bomsztyk K. Nuclear shift of hnRNP K protein in neoplasms and other states of enhanced cell proliferation. Brit J Cancer. 2003; 89:1493-1501.

18. Inoue A, Sawata SY, Taira K, Wadhwa R. Loss-of-function screening by randomized intracellular antibodies: identification of hnRNP-K as a potential target for metastasis. Proc Natl Acad Sci U S A. 2007; 104:8983-8988.

19. Carpenter B, MacKay C, Alnabulsi A, MacKay M, Telfer C, Melvin WT, Murray GI. The roles of heterogeneous nuclear ribonucleoproteins in tumour development and progression. Biochim Biophys Acta. 2006; 1765:85-100.

20. Ostareck-Lederer A, Ostareck DH, Cans C, Neubauer G, Bomsztyk K, Superti-Furga G, Hentze MW. c-Src-mediated phosphorylation of hnRNP K drives translational activation of specifically silenced mRNAs. Mol Cell Biol. 2002; 22:4535-4543.

21. Sataranatarajan K, Lee MJ, Mariappan MM, Feliers D. $\mathrm{PKC} \delta$ regulates the stimulation of vascular endothelial factor mRNA translation by angiotensin II through hnRNP K. Cell Signal. 2008; 20:969-977.

22. Habelhah H, Shah K, Huang L, Ostareck-Lederer A, Burlingame AL, Shokat KM, Hentze MW, Ronai Z. ERK phosphorylation drives cytoplasmic accumulation of hnRNP-K and inhibition of mRNA translation. Nat Cell Biol. 2001; 3:325-330.

23. Chen Y, Zhou X, Liu N, Wang C, Zhang L, Mo W, $\mathrm{Hu}$ G. Arginine methylation of hnRNP K enhances p53 transcriptional activity. FEBS Lett. 2008; 582:1761-1765.

24. Moumen A, Masterson P, O’Connor MJ, Jackson SP. hnRNP K: an HDM2 target and transcriptional coactivator of p53 in response to DNA damage. Cell. 2005; 123:1065-1078.

25. Li T, Evdokimov E, Shen RF, Chao CC, Tekle E, Wang T, Stadtman ER, Yang DC, Chock PB. Sumoylation of heterogeneous nuclear ribonucleoproteins, zinc finger proteins, and nuclear pore complex proteins: a proteomic analysis. Proc Natl Acad Sci U S A. 2004; 101:8551-8556.

26. Lee SW, Lee MH, Park JH, Kang SH, Yoo HM, Ka SH, Oh YM, Jeon YJ, Chung CH. SUMOylation of hnRNP-K is required for $\mathrm{p} 53$-mediated cell-cycle arrest in response to DNA damage. EMBO, J. 2012; 31:4441-4452.

27. Baber JL, Libutti D, Levens D, Tjandra N. High precision solution structure of the C-terminal $\mathrm{KH}$ domain of heterogeneous nuclear ribonucleoprotein $\mathrm{K}$, a c-myc transcription factor. J Mol Biol. 1999; 289:949-962.

28. Notari M, Neviani P, Santhanam R, Blaser BW, Chang JS, Galietta A, Willis AE, Roy DC, Caligiuri MA, Marcucci G, Perrotti D. A MAPK/HNRPK pathway controls BCR/ABL oncogenic potential by regulating $M Y C$ mRNA translation. Blood. 2006; 107:2507-2516.

29. Wilkinson KA, Henley JM. Mechanisms, regulation and consequences of protein SUMOylation. Biochem J. 2010; 428:133-145.

30. Yeh ET, Gong L, Kamitani T. Ubiquitin-like proteins: new wines in new bottles. Gene. 2000; 248:1-14.

31. Mo YY, Yu Y, Theodosiou E, Ee PL, Beck WT. A role for Ubc9 in tumorigenesis. Oncogene. 2005; 24:2677-2683.

32. Kim JH, Choi HJ, Kim B, Kim MH, Lee JM, Kim IS, Lee MH, Choi SJ, Kim KI, Kim SI, Chung CH, Baek SH. Roles of sumoylation of a reptin chromatin-remodelling complex in cancer metastasis. Nat Cell Biol. 2006; $8: 631-639$.

33. Moriyama Y, Nishiguchi S, Tamori A, Koh N, Yano Y, Kubo S, Hirohashi K, Otani S. Tumor-suppressor effect of interferon regulatory factor-1 in human hepatocellular carcinoma. Clin Cancer Res. 2001; 7:1293-1298.

34. Ma KW, Au SW, Waye MM. Over-expression of SUMO-1 induces the up-regulation of heterogeneous nuclear ribonucleoprotein A2/B1 isoform B1 (hnRNP A2/B1 isoform B1) and uracil DNA glycosylase (UDG) in hepG2 cells. Cell Biochem Funct. 2009; 27:228-237.

35. Vassileva MT, Matunis MJ. SUMO modification of heterogeneous nuclear ribonucleoproteins. Mol Cell Biol. 2004; 24:3623-3632.

36. Tempe D, Piechaczyk M, Bossis G. SUMO under stress. Biochem Soc Trans. 2008; 36:874-878.

37. Ritchie SA, Pasha MK, Batten DJ, Sharma RK, Olson DJ, Ross AR, Bonham K. Identification of the SRC pyrimidinebinding protein (SPy) as hnRNP K: implications in the regulation of SRC1A transcription. Nucleic acids research. 2003; 31:1502-1513.

38. Michelotti EF, Michelotti GA, Aronsohn AI, Levens D. Heterogeneous nuclear ribonucleoprotein $\mathrm{K}$ is a transcription factor. Mol Cell Biol. 1996; 16:2350-2360.

39. Chen LC, Chung IC, Hsueh C, Tsang NM, Chi LM, Liang Y, Chen CC, Wang LJ, Chang YS. The antiapoptotic protein, FLIP, is regulated by heterogeneous nuclear ribonucleoprotein $\mathrm{K}$ and correlates with poor overall survival of nasopharyngeal carcinoma patients. Cell Death Differ. 2010; 17:1463-1473.

40. Chen LC, Liu HP, Li HP, Hsueh C, Yu JS, Liang CL, Chang YS. Thymidine phosphorylase mRNA stability and protein levels are increased through ERK-mediated cytoplasmic accumulation of hnRNP K in nasopharyngeal carcinoma cells. Oncogene. 2009; 28:1904-1915.

41. Ostareck DH, Ostareck-Lederer A, Shatsky IN, Hentze MW. Lipoxygenase mRNA silencing in erythroid differentiation: The 3'UTR regulatory complex controls $60 \mathrm{~S}$ ribosomal subunit joining. Cell. 2001; 104:281-290.

42. Shi Y, Frost PJ, Hoang BQ, Benavides A, Sharma S, Gera JF, Lichtenstein AK. IL-6-induced stimulation of c-Myc translation in multiple myeloma cells is mediated 
by myc internal ribosome entry site function and the RNA-binding protein, hnRNP A1. Cancer Res. 2008; 68:10215-10222.

43. Sekiguchi N1, Ootsubo K, Wagatsuma M, Midorikawa K, Nagata A, Noto S, Yamada K, Takezako N. The impact of C-Myc gene-related aberrations in newly diagnosed myeloma with bortezomib/dexamethasone therapy. Int $\mathrm{J}$ Hematol. 2014; 99:288-295.

44. Chng WJ, Huang GF, Chung TH, Ng SB, Gonzalez-Paz N, Troska-Price T, Mulligan G, Chesi M, Bergsagel PL, Fonseca R. Clinical and biological implications of MYC activation: a common difference between MGUS and newly diagnosed multiple myeloma. Leukemia. 2011; 25:1026-1035.

45. Zhang M, He J, Liu Z, Lu Y, Zheng Y, Li H, Xu J, Liu H, Qian J, Orlowski RZ, Kwak LW, Yi Q, Yang J. Anti- $\beta$ Bmicroglobulin monoclonal antibodies overcome bortezomib resistance in multiple myeloma by inhibiting autophagy. Oncotarget. 2015; 6:8567-8578.

46. Leshchenko VV, Kuo PY, Jiang Z, Weniger MA, Overbey J, Dunleavy K, Wilson WH, Wiestner A, Parekh S. Harnessing Noxa demethylation to overcome Bortezomib resistance in mantle cell lymphoma. Oncotarget. 2015 Feb 3. PMID: 25714012.

47. Lee WH, Wu HH, Huang WJ, Li YN, Lin RJ, Lin SY, Liang YC. N-Hydroxycinnamide derivatives of osthole ameliorate hyperglycemia through activation of AMPK and p38 MAPK. Molecules. 2015; 20:4516-4529.

48. Chin LH, Hsu SP, Zhong WB, Liang YC. Combined treatment with troglitazone and lovastatin inhibited epidermal growth factor-induced migration through the downregulation of cysteine-rich protein 61 in human anaplastic thyroid cancer cells. PLOS ONE. 2015; 10:e0118674.

49. Chin LH, Hsu SP, Zhong WB, Liang YC. Involvement of cysteine-rich protein 61 in the epidermal growth factorinduced migration of human anaplastic thyroid cancer cells. Mol Carcinog. 2015; doi: 10.1002/mc.22308. [Epub ahead of print].

50. Liu LY, Huang WJ, Ho FM, Lin RJ, Lin SY, Suk FM, Liang YC. N-Hydroxycinnamide derivatives of osthole inhibit cell migration and invasion by suppressing Smad2 and Akt pathways in human colorectal adenocarcinoma cells. Chem Biol Interact. 2014; 217:1-8. 